DOI: https://doi.org/10.31933/dijemss.v2i5

Received: 25 June 2021, Revised: 10 July 2021, Publish: 31 July 2021

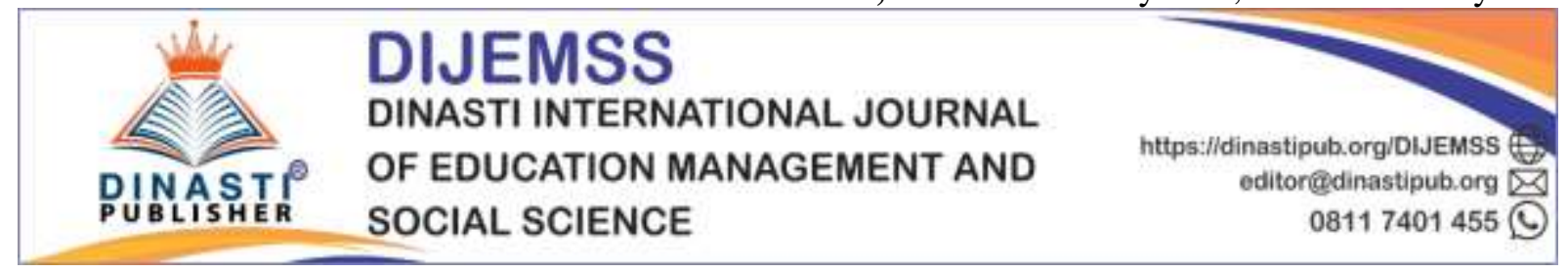

\title{
EFFECT OF COMPRESSOR CARGO SUCTION PRESSURE AND TANK PRESSURE ON THE LENGTH OF THE RELIQUEFACTION PROCESS ON LPG/C GRIYA BORNEO
}

\author{
Bambang Sumali ${ }^{1}$, April Gunawan², Larsen Barasa ${ }^{3}$, Rika Desy Anggraini ${ }^{4}$ \\ 1) Merchant Marine Higher Education, bambs511@gmail.com \\ 2) Merchant Marine Higher Education \\ 3) Merchant Marine Higher Education \\ 4) Merchant Marine Higher Education
}

\section{Corresponding Author: Bambang Sumali}

\begin{abstract}
LPG / C Griya Borneo is a gas vessel with a semi-pressurized type, where the supporting components in the form of cargo handling equipment have a very big influence on the success and safety of ship operations. This is important to note because when the ship will carry out the loading process, the load temperature must be in accordance with the boiling point. High temperatures on ammonia loads can increase the pressure in the tank so that it exceeds the specified pressure limits and ammonia loads that have high temperatures need to be reliquefaction. In addition, the compressor compressor suction pressure that does not work in accordance with what is expected to affect the reliability process. This resulted in the reliquefaction process being longer than usual. The long reliquefaction process results in more fuel being used so that it costs a lot. Therefore the writer makes a thesis related to the problems experienced by the ship owned by PT Humpuss Transportasi Kimia aims to find out how much influence the compressor compressor suction pressure and tank pressure on the process of reliquefaction on the LPG / C Griya Borneo ship, the place where the authors practice.
\end{abstract}

Keywords: Compressor cargo suction pressure, tank pressure, and the duration of the reliquefaction process

\section{INTRODUCTION}

Gas transport vessels (Ammonia) have tanks made of stainless steel that can carry liquefied gas loads. Gas is always transported in liquid form for the simple reason that the volume of gas in liquid form is much smaller than in the form of gas if placed in a room that has the same size, based on these principles, the volume or weight of the gas charge that can be transported in liquid form 
is also become bigger. Handling of liquefied gas on board a ship is needed to maintain the quality and quantity of the product being transported and of course to ensure the ship stays in a safe condition. Handling of cargo is not only necessary when loading or unloading cargo, but also as long as the cargo is transported from the loading port to the loading port, LPG / C Griya Borneo is a gas vessel with a semi-pressurized type, where the supporting components in the form of cargo handling equipment have a very big influence on the success and safety of ship operations. It is important to pay attention to the temperature and pressure conditions in the tank because the Ammonia gas is loaded in a state of outside air pressure and at low temperatures. Then the tank must be able to withstand the situation. High temperatures on the load can increase the pressure in the tank so that it exceeds the specified pressure limit.

In LPG / C Griya Borneo there is a reliquefaction plant that functions to carry out the process of cargo quenching (reliquefaction). Broadly speaking, the charge cooling system functions to change the charge in a vapor-shaped tank back into a liquid form. This system works to suck the steam from the tank then pressed until the pressure and temperature increase. Then the compressed vapor will be condensed which results in the form of liquid or called condensate which will be flowed back into the tank with a condensate return system so that it can reduce the temperature and pressure of the charge in the tank. With this, the stability of temperature and pressure in the tank must be maintained.

Compressor cargo suction pressure that does not work as expected can affect the reliquefaction process. This resulted in the reliquefaction process being longer than usual. The long reliquefaction process results in more fuel being used so that it costs a lot.

Ammonia load is one type of dangerous cargo so the lack of quality of ship officers' knowledge in the operation of cargo compressor causes the load quenching process (reliquefaction) to take a long time. In addition, the lack of cargo compressor maintenance can result in the performance of the cargo compressor not in accordance with what is expected. Considering the extent of the problem regarding the reliquefaction process and to be more focused and directed in restraining, the authors limit the discussion to the effect of cargo compressor suction pressure and tank pressure on the length of the rliquefaction process.

The purpose of this research is to determine the effect of cargo compressor suction pressure on the duration of the reliquefaction process, determine the effect of tank pressure on the duration of the reliquefaction process, determine the effect of the compressor compressor suction pressure and compressor pressure together on the duration of the reliquefaction process.

The benefits of this research are divided into two, namely, theoretical aspects, namely for the academic world, this research can provide knowledge about the effect of cargo compressor suction pressure and tank pressure on the length of the process of reliquefaction to the readers. officers and crew regarding the compressor compressor suction pressure and tank pressure on the duration of the reliquefaction process.

\section{METHOD}

\section{Data Description}

Compressor Cargo Suction Pressure 
Compressor cargo suction pressure is the ability of the compressor cargo to suck the Vapor in the tank to be turned into liquid. The following is a recapitulation of cargo compressor suction pressure (X1) from voyage from August 2018 to August 2019, including:

Table 1 Compressor Cargo Suction Pressure from August 2018 to August 2019

\begin{tabular}{|c|c|c|}
\hline No. & Voyage & X1 (Bar) \\
\hline 1 & Voyage 1 & 0.9 \\
\hline 2 & Voyage 2 & 0.6 \\
\hline 3 & Voyage 3 & .74 \\
\hline 4 & Voyage 4 & 1,1 \\
\hline 5 & Voyage 5 & 0.8 \\
\hline 6 & Voyage 6 & 1,1 \\
\hline 7 & Voyage 7 & 1,3 \\
\hline 8 & Voyage 8 & 0.7 \\
\hline 9 & Voyage 9 & 0.8 \\
\hline 10 & Voyage 10 & 0.6 \\
\hline 11 & Voyage 11 & 0.8 \\
\hline 12 & Voyage 12 & 0.8 \\
\hline 13 & Voyage 13 & .73 \\
\hline 14 & Voyage 14 & 1 \\
\hline 15 & Voyage 15 & 1.62 \\
\hline 16 & Voyage 16 & 0.9 \\
\hline 17 & Voyage 17 & 1 \\
\hline 18 & Voyage 18 & 1 \\
\hline 19 & Voyage 19 & .74 \\
\hline 20 & Voyage 20 & 0.85 \\
\hline 21 & Voyage 21 & 1,1 \\
\hline 22 & Voyage 22 & 0.8 \\
\hline 23 & Voyage 23 & 1 \\
\hline 24 & Voyage 24 & .76 \\
\hline 25 & Voyage 25 & 1,1 \\
\hline 26 & Voyage 26 & .78 \\
\hline 27 & Voyage 27 & .86 \\
\hline 28 & Voyage 28 & 0.8 \\
\hline 29 & Voyage 29 & 0.68 \\
\hline 30 & Voyage 30 & 0.8 \\
\hline 31 & Voyage 31 & 1.05 \\
\hline 32 & Voyage 32 & 0.9 \\
\hline 33 & Voyage 33 & .67 \\
\hline 34 & Voyage 34 & 0.8 \\
\hline 35 & Voyage 35 & .89 \\
\hline 36 & Voyage 36 & 0.8 \\
\hline \multicolumn{2}{|c|}{ Total } & 31.87 \\
\hline \multicolumn{2}{|c|}{ Average } & 0.88 \\
\hline
\end{tabular}

\section{Tank Pressure}

Tank pressure is the pressure at which a substance is in a liquid state at its critical temperature. The following is a recapitulation of the Load Tank (X2) from August 2018 to August 2019, including: 
Table 2 Tank Pressure from August 2018 to August 2019

\begin{tabular}{|c|c|c|}
\hline No. & Voyage & X2 (Bar) \\
\hline 1 & Voyage 1 & 0.62 \\
\hline 2 & Voyage 2 & 0.32 \\
\hline 3 & Voyage 3 & 0.4 \\
\hline 4 & Voyage 4 & .89 \\
\hline 5 & Voyage 5 & 0.6 \\
\hline 6 & Voyage 6 & 0.69 \\
\hline 7 & Voyage 7 & 1.19 \\
\hline 8 & Voyage 8 & .36 \\
\hline 9 & Voyage 9 & 0.42 \\
\hline 10 & Voyage 10 & 0.25 \\
\hline 11 & Voyage 11 & 0.25 \\
\hline 12 & Voyage 12 & 0.53 \\
\hline 13 & Voyage 13 & 0.45 \\
\hline 14 & Voyage 14 & 0.9 \\
\hline 15 & Voyage 15 & 1.07 \\
\hline 16 & Voyage 16 & 0.55 \\
\hline 17 & Voyage 17 & .83 \\
\hline 18 & Voyage 18 & 0.69 \\
\hline 19 & Voyage 19 & .19 \\
\hline 20 & Voyage 20 & 0.44 \\
\hline 21 & Voyage 21 & .94 \\
\hline 22 & Voyage 22 & 0.25 \\
\hline 23 & Voyage 23 & 0.7 \\
\hline 24 & Voyage 24 & 0.48 \\
\hline 25 & Voyage 25 & 0.9 \\
\hline 26 & Voyage 26 & 0.51 \\
\hline 27 & Voyage 27 & 0.31 \\
\hline 28 & Voyage 28 & 0.5 \\
\hline 29 & Voyage 29 & 0.23 \\
\hline 30 & Voyage 30 & 0.4 \\
\hline 31 & Voyage 31 & 0.88 \\
\hline 32 & Voyage 32 & 0.61 \\
\hline 33 & Voyage 33 & 0.45 \\
\hline 34 & Voyage 34 & 0.25 \\
\hline 35 & Voyage 35 & 0.66 \\
\hline 36 & Voyage 36 & 0.6 \\
\hline \multicolumn{2}{|c|}{ Total } & 20.31 \\
\hline \multicolumn{2}{|c|}{ Average } & 0.56 \\
\hline
\end{tabular}

\section{The duration of the Reliquefaction Process}

Reliquefaction is the process of melting vapor into liquid on a Gas Carrier that aims to maintain the pressure and temperature in the tank. On the Gas Carrier vapor ship is counted as a cargo, the vapor must be reliquefaction so that it turns into liquid again. Reliquefaction takes a long time if the rallyquefaction plant does not work optimally.

The following is a recapitulation of the length of the reliquefaction (Y) process from August 2018 to August 2019, including: 
Table 3 Length of the Reliquefaction Process from August 2018 to August 2019

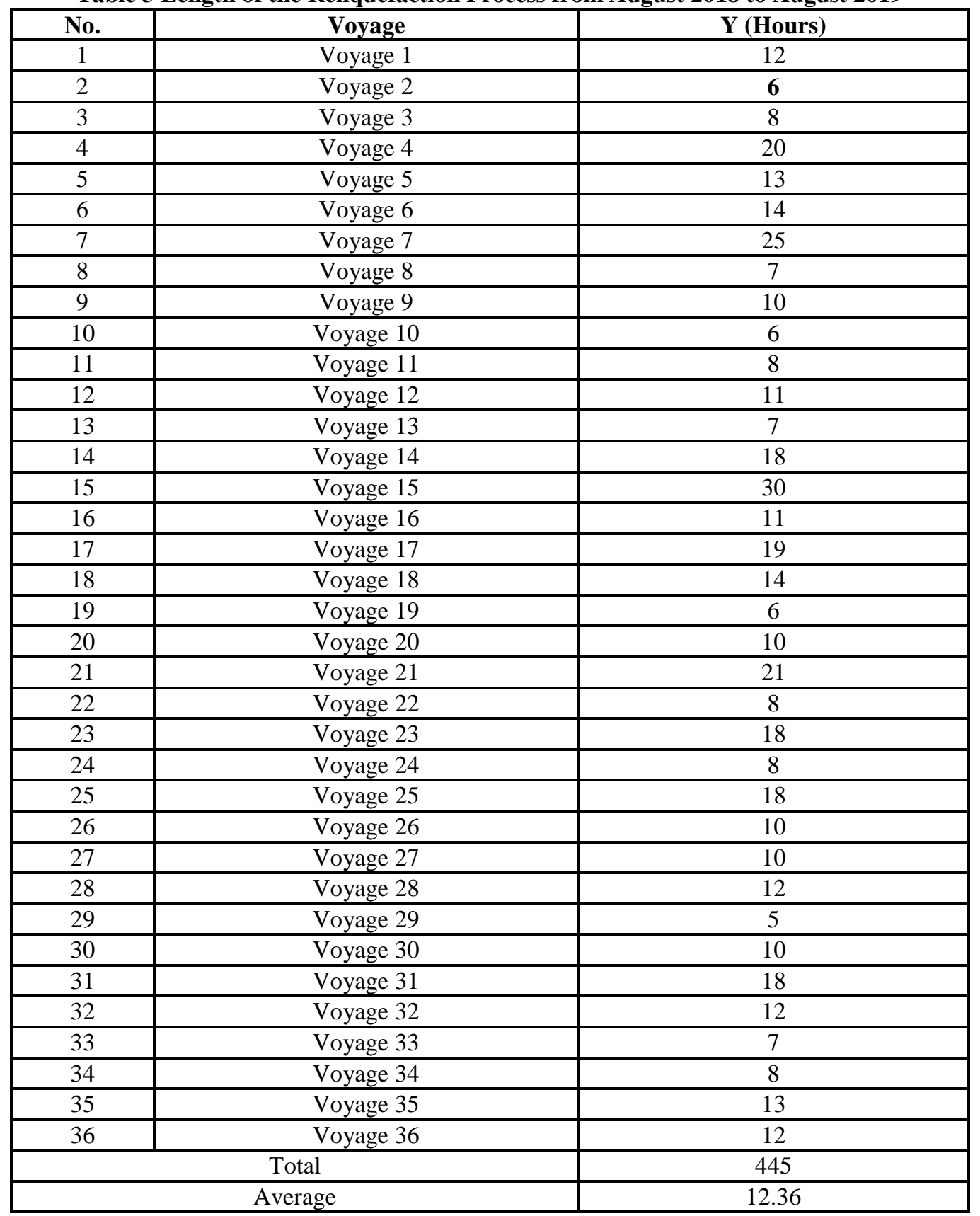

\section{Research time}

This research was conducted at the time the authors conducted Marine Practices on LPG / C Griya Borneo ships from 20 August 2018 to 27 August 2019.

\section{Place of Research}

This research was conducted by the author on the LPG / C Griya Borneo Ship 


\section{Approach Method}

In this study using a quantitative data approach method. In this study the data obtained and analyzed in the form of secondary data, that is data that has been obtained from reading scientific literature that has a close relationship with the object of research, namely the length of the process of reliquifaction. For example, the authors get data on compressor compressor suction pressure in 2019, tank pressure in 2019 and definitions of understanding from reference books in the library, etc.

\section{Data collection technique}

In completing this thesis the author collects data and information needed to complete this thesis material by using "Field Research". Field research is research to obtain the necessary data through direct observation and interviews as well as taking secondary data about LPG / C Griya Borneo ships. In this field research using the following techniques.

a. Observation

Observation is a method of collecting data where research records information as they witnessed it during the study. Witnessing these events can be seen, heard, felt and then recorded subjectively. (Gulo, 2002: 116).

Maybe people often interpret the observation of a narrow asset, which is paying attention to something using the eyes. In the sense of psychology, observation or also called observation includes the activity of loading attention to an object by using all the senses. So observing can be done through vision, smell, hearing, touch, and taste. What this says is actually a direct observation (Prof. Dr. Suharsimi Arikunto, 2006: 156) In this technique, the author uses research directly by visiting the place under study. In this observation researchers looked directly and observed the activities of reliquifaction. Where in the observation section, the authors observe the results of the rally activity and pay attention to the compressor compressor suction pressure and pressure tank.

b. Documentation

Documents are records of various activities or events in the past, all documents relating to the relevant research need to be recorded as a source of information (Gulo, 2002:123). According to Prof. Dr. Suharsimi Arikunto (2006: 158), documentation comes from the origin of said documents which means written goods.

In carrying out the method of documentation, researchers investigate written objects such as books, magazines, documents, regulations, minutes of meetings, diaries, and so on.

From the study of this document the authors obtain data in the form of a recapitulation of the activities of the 2019 reliquifaction, in which there are data in the form of a compressor cargo suction pressure, tank pressure and time of the rally.

c. Literature review

Namely the collection of data by reading, viewing, researching, quoting from the books or references presented, input or material consideration and comparison regarding what can be seen from existing theories.

This literature study aims to obtain the basics of theory by reading books including regulations and other documents relating to the problem to be discussed.

In taking data by means of literature study taken from books and references, among others: 
1. Liquified Gas Handling Principles on Ship's and Terminals, 4th Edition, McGuire and White.

2. Tanker Safety Guide (Liquified Gas), 3rd Edition, International Chamber of Shipping.

3. Properties of Gases and Liquids

4. Mechanical Engineering Cooling

5. Operational Manual Cargo Handling System - Cryogas Vol 1 \& 2

\section{RESEARCH SUBJECT}

The population consists of a collection of objects that are the center of attention, which contain information that wants to be known (Gulo, 2002: 76).

The sample is a subset of a population, the sample provides a true picture of the population. Taking a sample from a population is called sampling. The population that is sampled when planning a study is called the target population, while the population that is studied when conducting research is called the sampling population (Gulo, 2002:78)

In this case, the population taken by the author in the preparation of this thesis is the data of all reliquefaction activities and the data taken is compressor compressor suction pressure and tank pressure.

\section{Results and Discussion}

The following is a recapitulation of compressor compressor suction pressure (X1), tank pressure (X2) and the length of the reliquefaction (Y) process from August 2018 to August 2019, including:

Table 4 Compressor Cargo Suction Pressure (X1), Tank Pressure (X2) and Reliquefaction Duration (Y)

\begin{tabular}{|l|c|c|c|}
\hline \multicolumn{1}{|c|}{ Voyage } & X1 (Bar) & X2 (Bar) & Y (Hours) \\
\hline Voyage 1 & 0.9 & 0.62 & 12 \\
\hline Voyage 2 & 0.6 & 0.32 & $\mathbf{6}$ \\
\hline Voyage 3 & .74 & 0.4 & 8 \\
\hline Voyage 4 & 1,1 & .89 & 20 \\
\hline Voyage5 & 0.8 & 0.6 & 13 \\
\hline Voyage 6 & 1,1 & 0.69 & 14 \\
\hline Voyage 7 & 1,3 & 1.19 & 25 \\
\hline Voyage 8 & 0.7 & .36 & 7 \\
\hline Voyage 9 & 0.8 & 0.42 & 10 \\
\hline Voyage 10 & 0.6 & 0.25 & 6 \\
\hline Voyage 11 & 0.8 & 0.25 & 8 \\
\hline Voyage 12 & 0.8 & 0.53 & 11 \\
\hline Voyage 13 & .73 & 0.45 & 7 \\
\hline Voyage 14 & 1 & 0.9 & 18 \\
\hline Voyage 15 & 1.62 & 1.07 & 30 \\
\hline Voyage 16 & 0.9 & 0.55 & 11 \\
\hline Voyage 17 & 1 & .83 & 19 \\
\hline Voyage 18 & 1 & 0.69 & 14 \\
\hline Voyage 19 & .74 & .19 & 6 \\
\hline Voyage 20 & 0.85 & 0.44 & 10 \\
\hline Voyage 21 & 1,1 & .94 & 21 \\
\hline Voyage 22 & 0.8 & 0.25 & 8 \\
\hline Voyage 23 & 1 & 0.7 & 18 \\
\hline
\end{tabular}




\begin{tabular}{|l|c|c|c|} 
Voyage 24 & .76 & 0.48 & 8 \\
\hline Voyage 25 & 1,1 & 0.9 & 18 \\
\hline Voyage 26 & .78 & 0.51 & 10 \\
\hline Voyage 27 & .86 & 0.31 & 10 \\
\hline Voyage 28 & 0.8 & 0.5 & 12 \\
\hline Voyage 29 36 & 0.68 & 0.23 & 5 \\
\hline Voyage 30 & 0.8 & 0.4 & 10 \\
\hline Voyage 31 30. & 1.05 & 0.88 & 18 \\
\hline Voyage 32 & 0.9 & 0.61 & 12 \\
\hline Voyage 33 & .67 & 0.45 & 7 \\
\hline Voyage 34 & 0.8 & 0.25 & 8 \\
\hline Voyage 35 & .89 & 0.66 & 13 \\
\hline Voyage 36 & 0.8 & 0.6 & 12 \\
\hline Total & 31.87 & 20.31 & 445 \\
\hline Average & 0.88 & 0.56 & 12.36 \\
\hline
\end{tabular}

The Relationship between Compressor Cargo Suction Pressure (X1) and the Length of Reliquefaction (Y)

Table 5 Results of Compressor Cargo Suction Pressure Analysis (X1) againstThe Length of the Reliquefaction Process (Y)

\begin{tabular}{|c|c|c|c|c|}
\hline $\mathbf{X}$ & $\mathbf{Y}$ & $\mathbf{X 1 Y}$ & $\mathbf{( X 1 ) ~ 2}$ & $\mathbf{Y 2}$ \\
\hline 0.9 & 12 & 10.8 & .81 & 144 \\
\hline 0.6 & 6 & 3,6 & .36 & 36 \\
\hline .74 & 8 & 5.92 & 0.5476 & 64 \\
\hline 1,1 & 20 & 22 & 1.21 & 400 \\
\hline 0.8 & 13 & 10.4 & 0.64 & 169 \\
\hline 1,1 & 14 & 15.4 & 1.21 & 196 \\
\hline 1,3 & 25 & 32.5 & 1.69 & 625 \\
\hline 0.7 & 7 & 4.9 & 0.49 & 49 \\
\hline 0.8 & 10 & 8 & 0.64 & 100 \\
\hline 0.6 & 6 & 3,6 & .36 & 36 \\
\hline 0.8 & 8 & 6,4 & 0.64 & 64 \\
\hline 0.8 & 11 & 8.8 & 0.64 & 121 \\
\hline 0.73 & 7 & 5,11 & 0.5329 & 49 \\
\hline 1 & 18 & 18 & 1 & 324 \\
\hline 1.62 & 30 & 48.6 & 2,6244 & 900 \\
\hline 0.9 & 11 & 9.9 & .81 & 121 \\
\hline 1 & 19 & 19 & 1 & 361 \\
\hline 1 & 14 & 14 & 1 & 196 \\
\hline 0.74 & 6 & 4.44 & 0.5476 & 36 \\
\hline 0.85 & 10 & 8.5 & .7225 & 100 \\
\hline 1,1 & 21 & 23.1 & 1.21 & 441 \\
\hline 0.8 & 8 & 6,4 & 0.64 & 64 \\
\hline 1 & 18 & 18 & 1 & 324 \\
\hline 0.76 & 8 & 6.08 & 0.5776 & 64 \\
\hline 1,1 & 18 & 19.8 & 1.21 & 324 \\
\hline 0.78 & 10 & 7.8 & 0.6084 & 100 \\
\hline 0.86 & 10 & 8.6 & 0.7396 & 100 \\
\hline 0.8 & 12 & 9.6 & 0.64 & 144 \\
\hline
\end{tabular}




\begin{tabular}{|c|c|c|c|c|}
\hline 0.68 & 5 & 3,4 & .4624 & 25 \\
\hline 0.8 & 10 & 8 & 0.64 & 100 \\
\hline 1.05 & 18 & 18.9 & 1,1025 & 324 \\
\hline 0.9 & 12 & 10.8 & .81 & 144 \\
\hline 0.67 & 7 & 4.69 & 0.4489 & 49 \\
\hline 0.8 & 8 & 6,4 & 0.64 & 64 \\
\hline 0.89 & 13 & 11.57 & .7921 & 169 \\
\hline 0.8 & 12 & 9.6 & 0.64 & 144 \\
\hline 31.87 & 445 & 432.61 & 29,6365 & 6671 \\
\hline
\end{tabular}

Calculation of the correlation between the variables X1 and Y. Based on the table above, the numbers can be obtained through statistics as follows:

\section{Validity test}

Validity test is performed to determine the level of reliability and validity of the compressor compressor (X1) suction pressure variable for the length of the reliqufaction (Y) process, using the same validity formula as the correlation coefficient formula as follows.

$$
\begin{aligned}
& r_{x 1 y}=\frac{n \cdot \sum X_{1} Y \cdot-\sum X_{1} \cdot \sum Y}{\sqrt{n \cdot \sum X_{1}{ }^{2}-\left(\sum X_{1}\right)^{2}} \sqrt{n \cdot \sum Y^{2}-\left(\sum Y\right)^{2}}} . \\
& r_{x 1 y}=\frac{(36)(432,61)-(31,87)(445)}{\sqrt{(36) 29,6365-(31,87)^{2}} \cdot \sqrt{(36) 6.671-(445)^{2}}} \\
& r_{x 1 y}=\frac{15 \cdot 573,96-14 \cdot 182,15}{\sqrt{1.066,914-1 \cdot 015,6969} \cdot \sqrt{240.156-198.025}} \\
& r_{x 1 y}=\frac{1.391,81}{\sqrt{51,2171} \cdot \sqrt{42131}} \\
& r_{x 1 y}=\frac{1.391,81}{(7,1566)(205,2583)} \\
& r_{x 1 y}=\frac{1.391,81}{1.468,9515} \\
& r_{x 1 y}=0,94
\end{aligned}
$$

Can be concluded :

If $\mathrm{r}$ arithmetic $<\mathrm{r}$ table, the research statement is invalid.

If $r$ count $>r$ table, then the research statement is said to be valid.

To prove the validity of the compressed cargo suction pressure variable (X1) to the length of the reliquefaction process (Y) according to the calculation obtained on the correlation coefficient number of (0.94), so that the validity number of (0.94) is done is to find the count that is based on the criteria with the provisions of $\mathrm{df}$ (degree of freedom) with the value of $\mathrm{n}$ (number of samples) known 36 (thirty six), $\mathrm{df}=\mathrm{n}-2$ then it becomes $\mathrm{df}=36-2$ that is 34 then compared rtable at $\alpha=$ 0.05 ; then it is 0.339 (from rtable). 
Then, the results obtained are $r 1=r$ count $=0.94$, because $r$ count $>r$ table $(0.94>0.339)$. So it can be concluded that the compressor compressor suction pressure variable (X1) over the duration of the reliquefaction (Y) process is declared valid.

\section{Reliability Test}

In this study, the authors did not use the reliability test because the data I used were secondary data not based on a research questionnaire.

\section{Regression Correlation Coefficient Analysis}

To find out the strength or weakness of the relationship between the variables X1 and Y, then this analysis will find the value of $r$ (correlation coefficient), namely by the formula:

Regression Correlation Coefficient Formula $=$ Validity Test Formula

$$
r_{x 1 y}=\frac{n \cdot \sum X_{1} Y \cdot-\sum X_{1} \cdot \sum Y}{\sqrt{n \cdot \sum X_{1}^{2}-\left(\sum X_{1}\right)^{2}} \sqrt{n \cdot \sum Y^{2}-\left(\sum Y\right)^{2}}} .
$$

$r_{x 1 y}=0,94$

From the above calculation, the correlation coefficient figure is (0.947), it means that there is a strong influence between the compressor compressor suction pressure on the length of the reliquefaction process. If the correlation results are positive, it can be interpreted if the compressor suction pressure of the compressor increases then it takes a long time to reliquefaction. Vice versa, if there is a decrease in the cargo compressor suction pressure it will not require a short time reliquefaction.

\section{Determination Coefficient Analysis (KD = R2)}

Analysis of the coefficient of determination is to find out how much the contribution of the compressor cargo suction pressure (X1) toThe duration of the reliquefaction (Y) process is used the coefficient of determination formula as follows:

$\mathrm{KD}=\mathrm{r} 2 \times 100 \%$

$\mathrm{KD}=(0.94)^{2} \times 100 \%$

$\mathrm{BC}=0.88 \times 100 \%$

$\mathrm{KD}=88 \%$

Information :

$\mathrm{KD} \quad=$ Coefficient of determination

rxy $\quad=$ Correlation coefficient $\mathrm{X}$ and $\mathrm{Y}$

With a regression line value $(\mathrm{r} 2=0.88)$ close to 1 , it is said to be feasible to use. Then the coefficient of determination is $88 \%$ shows that the value is worth continuing to predict by using a regression formula where $88 \%$ of the cargo compressor suction pressure affects the duration of the reliquefaction process and $12 \%$ by other factors.

\section{Hypothesis testing}

Hypothesis testing about the correlation coefficient. Judging from the calculation of the correlation coefficient, determination and regression lines, then the hypothesis test can be done to 
determine the effect of the compressor compressor suction pressure on the length of the process of reliquefaction on the LPG / C Griya Borneo ship.

1) Partial Correlation Coefficient Test (T Test)

Hypothesis tests used by the authors are as follows:

If tcount <ttable then Ho is accepted and $\mathrm{H} 1$ is rejected, it means that there is no significant relationship between compressor compressor suction pressure on the length of the reliquefaction process on the LPG / C Griya Borneo ship.

If tcount> ttable, then Ho is rejected and $\mathrm{H} 1$ is accepted, meaning that there is a significant relationship between compressor compressor suction pressure on the length of the process of reliquefaction on the LPG / C Griya Borneo Vessel.

To prove that $\mathrm{H} 1$ is accepted or rejected, then what is done is to find t-count by entering the value (r) into the formula, the value of $n$ (number of samples) is known 36 (three six), then compared to the table at $\alpha=0.05 ; \mathrm{df}=\mathrm{nk}$ where $\mathrm{k}$ is the number of variables (free + bound) and $\mathrm{n}$ is the number of observations / samples forming the regression. So $\mathrm{df}=36-2=34$ is 1.69092 (from the table).

$\mathrm{t} 2=\mathrm{t}$ count

$\mathrm{t} 2=15.82$

$$
\begin{aligned}
\frac{r \sqrt{n-2}}{\sqrt{1-(r)^{2}}}= & \frac{(0,94) \sqrt{36-2}}{\sqrt{1-\left(0,94^{2}\right)}}=\frac{(0,94) \sqrt{34}}{\sqrt{1-0,88}}=\frac{(0,94) \cdot 5,83}{\sqrt{0,12}} \\
& =\frac{5,4802}{0,3464}
\end{aligned}
$$

Then, the results obtained are $\mathrm{t} 1=\mathrm{tcount}=15.82$, because tcount $>\mathrm{t}$ table $(15.82>1.69092)$. So Ho is rejected and $\mathrm{H} 1$ is accepted, meaning that there is a significant relationship between $\mathrm{X} 1$ and $\mathrm{Y}$. So that there is a significant relationship between the compressed cargo suction pressure on the length of the process of reliquefaction on the LPG / C Griya Borneo ship.

2) Simultaneous Correlation Coefficient Test (Test F)

Hypothesis tests used by the authors are as follows:

If the count is <ftable, then Ho is accepted and $\mathrm{H} 1$ is rejected, meaning that there is no significant relationship between the compressor cargo suction pressure on the length of the reliquefaction process on the LPG / C Griya Borneo ship.

If the count is > ftabel, then Ho is rejected and $\mathrm{H} 1$ is accepted, meaning that there is a significant relationship between the compressor cargo suction pressure on the length of the reliquefaction process on the LPG/C Griya Borneo ship

To prove that $\mathrm{H} 1$ is accepted or rejected, then what is done is to find a fcount that is by entering the value (r) into the formula, the value of $n$ (number of samples), degree of freedom (df) for the numerator or known as df1 with the symbol N1, degree of freedom (df) for the denominator, also known as df1with the symbol N2then compared ftabel at $\alpha=0.05$; df1 $=\mathrm{k}$ 1 ; df $2=\mathrm{nk}$ where $\mathrm{k}$ is the number of variables (free + bound) and $\mathrm{n}$ is the number of observations / samples forming the regression. Countable :

$$
\begin{array}{cl}
\text { df1 } & =\mathrm{k}-1 \\
=2-1 & =1 \\
\mathrm{df} 2 \quad & =\mathrm{n}-\mathrm{k} \\
=36-2 & =34
\end{array}
$$


So that $\mathrm{N} 1=1$ and $\mathrm{N} 2=34$ then ftabel $=4.13$.

$\mathrm{f} 1$ = fcount

fcount $=\frac{r^{2} / k}{1-r^{2} /(n-k-1)}=\frac{(0,94)^{2} / 2}{1-(0,94)^{2} /(36-2-1)}=\frac{0,88 / 2}{1-0,88 / 33}=\frac{0,44}{0,0036}=122.2$

Then, the results obtained are $\mathrm{f} 1=$ fcount $=122.2$, because fcount $>$ ftabel $(122.2>4.13)$. So $\mathrm{Ho}$ is rejected and $\mathrm{H} 1$ is accepted, meaning that there is a significant relationship between $\mathrm{X} 1$ and Y. So that there is a significant relationship between compressed cargo suction pressure on the length of the reliquefaction process on the LPG / C Griya Borneo ship.

\section{Correlation between Tank Pressure (X2) and the Length of the Reliquefaction (Y) Process}

Table 6

Tank Pressure (X2) against

The Length of the Reliquefaction Process(Y)

\begin{tabular}{|c|c|c|c|c|}
\hline $\mathrm{X} 2$ & $\mathbf{Y}$ & X2Y & (X2) 2 & Y2 \\
\hline 0.62 & 12 & 7.44 & 0.3844 & 144 \\
\hline 0.32 & 6 & 1.92 & .1024 & 36 \\
\hline 0.4 & 8 & 3,2 & .16 & 64 \\
\hline .89 & 20 & $\begin{array}{ll}17.8 \\
\end{array}$ & .7921 & 400 \\
\hline 0.6 & 13 & 7.8 & .36 & 169 \\
\hline 0.69 & 14 & 9.66 & 0.4761 & 196 \\
\hline 1.19 & 25 & 29.75 & 1,4161 & 625 \\
\hline .36 & 7 & 2.52 & 0.1296 & 49 \\
\hline 0.42 & 10 & 4.2 & 0.1764 & 100 \\
\hline 0.25 & 6 & 1.5 & 0.0625 & 36 \\
\hline 0.25 & 8 & 2 & 0.0625 & 64 \\
\hline 0.53 & 11 & 5.83 & 0.2809 & 121 \\
\hline 0.45 & 7 & 3.15 & 0.2025 & 49 \\
\hline 0.9 & 18 & 16.2 & .81 & 324 \\
\hline 1.07 & 30 & 32.1 & 1.1449 & 900 \\
\hline 0.55 & 11 & 6.05 & 0.3025 & 121 \\
\hline .83 & 19 & 15.77 & .6889 & 361 \\
\hline 0.69 & 14 & 9.66 & 0.4761 & 196 \\
\hline .19 & 6 & 1.14 & 0.0361 & 36 \\
\hline 0.44 & 10 & 4,4 & 0.1936 & 100 \\
\hline .94 & 21 & 19.74 & .8836 & 441 \\
\hline 0.25 & 8 & 2 & 0.0625 & 64 \\
\hline 0.7 & 18 & 12.6 & 0.49 & 324 \\
\hline 0.48 & 8 & 3.84 & 0.2304 & 64 \\
\hline 0.9 & 18 & 16.2 & .81 & 324 \\
\hline 0.51 & 10 & 5.1 & 0.2601 & 100 \\
\hline 0.31 & 10 & 3.1 & 0.0961 & 100 \\
\hline 0.5 & 12 & 6 & 0.25 & 144 \\
\hline 0.23 & 5 & 1.15 & 0.0529 & 25 \\
\hline 0.4 & 10 & 4 & .16 & 100 \\
\hline 0.88 & 18 & 15.84 & .7744 & 324 \\
\hline 0.61 & 12 & 7.32 & .3721 & 144 \\
\hline 0.45 & 7 & 3.15 & 0.2025 & 49 \\
\hline 0.25 & 8 & 2 & 0.0625 & 64 \\
\hline
\end{tabular}




\begin{tabular}{|c|c|c|c|c|}
\hline 0.66 & 13 & 8.58 & 0.4356 & 169 \\
\hline 0.6 & 12 & 7.2 & .36 & 144 \\
\hline 20.31 & 445 & 299.91 & 13,7603 & 6671 \\
\hline
\end{tabular}

Calculation of the correlation between the variables X2 and Y variables. Based on the table above, the numbers can be obtained through statistics as follows:

\section{Validity test}

Validity test is carried out to determine the level of reliability and validity of the tank pressure variable (X2) for the length of the reliquefaction (Y) process using the same validity formula with the correlation coefficient formula as follows.

$$
\begin{aligned}
& r_{x 2 y}=\frac{n \cdot \sum X_{2} Y-\sum X_{2} \cdot \sum Y}{\sqrt{n \cdot \sum X_{2}{ }^{2}-\left(\sum X_{2}\right)^{2}} \sqrt{n \cdot \sum Y^{2}-\left(\sum Y\right)^{2}}} . \\
& r_{x 2 y}=\frac{(36)(299,91)-(20,31)(445)}{\sqrt{(36) 13,7603-(20,31)^{2}} \cdot \sqrt{(36) 6.671-(445)^{2}}} \\
& r_{x 2 y}=\frac{10.796-9.037,95}{\sqrt{495,3708-412,4961} \cdot \sqrt{240.156-198.025}} \\
& r_{x 2 y}=\frac{1.758,05}{\sqrt{82,8747} \cdot \sqrt{42.131}} \\
& r_{x 2 y}=\frac{1.758,05}{(9,0817)(205,2583)} \\
& r_{x 2 y}=\frac{1.758,05}{1.864,09} \\
& r_{x 2 y}=0,94
\end{aligned}
$$

Can be concluded :

If $\mathrm{r}$ arithmetic $<\mathrm{r}$ table, the research statement is invalid.

If $r$ count $>r$ table, then the research statement is said to be valid.

To prove the validity of the tank pressure variable (X2) against the length of the reliquefaction process (Y) according to the calculations obtained on the correlation coefficient of (0.94), so that the validity number of $(0.94)$ is done is to find the rcount that is based on criteria with the provisions of $\mathrm{df}$ (degree of freedom) with the value of $\mathrm{n}$ (number of samples) known 36 (twelve), $\mathrm{df}=\mathrm{n}-2$ then it becomes $\mathrm{df}=36-2$ that is 34 then compared to rtable at $\alpha=0.05$; then it is 0.339 (from rtable).

Then, the results obtained are $r 1=r$ count $=0.94$, because $r$ count $>r$ table $(0.94>0.339)$. So it can be concluded that the tank pressure variable (X2) over the duration of the reliquefaction (Y) process is declared valid.

\section{Reliability Test}

In this study, the authors did not use the reliability test because the data I used were secondary data not based on a research questionnaire. 


\section{Regression Correlation Coefficient Analysis}

To find out the strength or weakness of the relationship between $\mathrm{X} 2$ and $\mathrm{Y}$ variables, then this analysis will find out the value of $r$ (correlation coefficient), namely by the formula:

Regression Correlation Coefficient Formula $=$ Validity Test Formula

$r_{x 2 y}=0,94$

$$
r_{x 2 y}=\frac{n \cdot \sum X_{2} Y-\sum X_{2} \cdot \sum Y}{\sqrt{n \cdot \sum X_{2}^{2}-\left(\sum X_{2}\right)^{2}} \sqrt{n \cdot \sum Y^{2}-\left(\sum Y\right)^{2}}} .
$$

From the above calculation, the correlation coefficient figure is ( 0.941$)$, it means that there is a strong influence between the Tank Pressure on the length of the reliquefaction process. If the correlation results are positive, it can be interpreted if the tank pressure increases, the duration of the reliquefaction process will also take a long time. Vice versa, if the tank pressure decreases, the duration of the reliquefaction process will be faster.

\section{Determination Coefficient Analysis (KD = R2)}

Analysis of the coefficient of determination is to find out how much the contribution of the variable berth output (X2) to Utilization of conventional dock (Y) used the coefficient of determination formula as follows:

$\mathrm{KD}=\mathrm{r} 2 \times 100 \%$

$\mathrm{BC}=(0.94) 2 \times 100 \%$

$\mathrm{BC}=0.88 \times 100 \%$

$\mathrm{KD}=88 \%$

Information :

$\mathrm{KD}=$ Coefficient of determination

rxy $=$ Correlation coefficient $\mathrm{X}$ and $\mathrm{Y}$

With a regression line value $(\mathrm{r} 2=0.88)$ close to 1 , it is said to be feasible to use. Then the coefficient of determination is $88 \%$ shows that the value is worth continuing to predict using a regression formula where $88 \%$ of the tank pressure affects the duration of the reliquefaction process and $12 \%$ by other factors.

\section{Hypothesis testing}

Hypothesis testing about the correlation coefficient. Judging from the calculation of the correlation coefficient, determination and regression lines, then the hypothesis test can be done to determine the effect of tank pressure on the length of the process of reliquefaction on the LPG / C Griya Borneo ship.

1) Partial Correlation Coefficient Test (T Test)

Hypothesis tests used by the authors are as follows: 
If tcount <ttable, Ho is accepted and $\mathrm{H} 2$ is rejected, meaning that there is no significant relationship between tank pressure and the duration of the reliquefaction process on the LPG / C Griya Borneo ship.

If tcount> ttable, then Ho is rejected and $\mathrm{H} 2$ is accepted, meaning that there is a significant relationship between the tank pressure and the duration of the reliquefaction on the LPG / C Griya Borneo ship.

To prove that $\mathrm{H} 2$ is accepted or rejected, then what is done is to find $\mathrm{t}$-counts by entering the value (r) into the formula, the value of $n$ (number of samples) is known 36 (twelve), then compared to the table at $\alpha=0.05 ; \mathrm{df}=\mathrm{nk}$ where $\mathrm{k}$ is the number of variables (free + bound) and $\mathrm{n}$ is the number of observations / samples forming the regression. So $\mathrm{df}=36-2=34$ is 1.69092 (from the table).

$\mathrm{t} 2=\mathrm{t}$ count

$\mathrm{t} 2=15.82 \frac{r \sqrt{n-2}}{\sqrt{1-(r)^{2}}}=\frac{(0,94) \sqrt{36-2}}{\sqrt{1-\left(0,94^{2}\right)}}=\frac{(0,94) \sqrt{34}}{\sqrt{1-0,88}}=\frac{(0,94) \cdot 5,83}{\sqrt{0,12}}=\frac{5,4802}{0,3464}$

Then, the results obtained are $\mathrm{t} 2=\mathrm{tcount}=15.82$, because tcount $>\mathrm{t}$ table $(15.82>1.69092)$. So Ho is rejected and $\mathrm{H} 2$ is accepted, meaning that there is a significant relationship between $\mathrm{X} 2$ and $\mathrm{Y}$. So there is a significant relationship between the tank pressure on the length of the process of reliquefaction on the LPG / C Griya Borneo ship.

2) Simultaneous Correlation Coefficient Test (Test F)

Hypothesis tests used by the authors are as follows:

If the count is <ftable, then Ho is accepted and $\mathrm{H} 2$ is rejected, meaning that there is no significant relationship between the tank pressure and the length of the reliquefaction process on the LPG / C Griya Borneo ship.

If the count is > ftabel, then Ho is rejected and $\mathrm{H} 2$ is accepted, meaning that there is a significant relationship between tank pressure and the length of the reliquefaction process on the LPG / C Griya Borneo ship.

To prove that $\mathrm{H} 2$ is accepted or rejected, then what is done is to find a fcount that is by entering the value ( $r$ ) into the formula, the value of $n$ (number of samples), degree of freedom (df) for the numerator or known as df1 with the symbol N1, degree of freedom (df) for the denominator, also known as df1with the symbol N2then compared ftabel at $\alpha=0.05$; df1 $=\mathrm{k}$ 1 ; $\mathrm{df} 2=\mathrm{nk}$ where $\mathrm{k}$ is the number of variables (free + bound) and $\mathrm{n}$ is the number of observations / samples forming the regression. Countable :

$$
\begin{array}{cl}
\text { df1 } & =\mathrm{k}-1 \\
=2-1 & =1 \\
\text { df2 } & =\mathrm{n}-\mathrm{k} \\
=36-2 & =34
\end{array}
$$

So that $\mathrm{N} 1=1$ and $\mathrm{N} 2=34$ then ftabel $=4.13$

$\mathrm{f} 2$ = fcount

fcount $\quad=\frac{r^{2} / k}{1-r^{2} /(n-k-1)}=\frac{(0,94)^{2} / 2}{1-(0,94)^{2} /(36-2-1)}=\frac{0,88 / 2}{1-0,88 / 33}=\frac{0,44}{0,0036}=122.2$

Then, the results obtained are $\mathrm{f} 2=\mathrm{fcount}=122.2$, because fcount $>$ ftabel $(122.2>4.13)$. So Ho is rejected and $\mathrm{H} 2$ is accepted, meaning that there is a significant relationship between $\mathrm{X} 2$ and Y. So there is a significant relationship between the tank pressure on the length of the process of reliquefaction on the LPG / C Griya Borneo ship. 
Correlation of Relationship between Compressor Cargo Suction Pressure (X1) and Tank Pressure (X2)

Table 7 Results of Compressor Cargo Suction Pressure Analysis (X1) Against Tank Pressure (X2)

\begin{tabular}{|c|c|c|c|c|}
\hline X1 & $\mathrm{X} 2$ & $\mathrm{X} 1 \mathrm{X} 2$ & (X1) 2 & (X2) 2 \\
\hline 0.9 & 0.62 & 0.558 & .81 & 0.3844 \\
\hline 0.6 & 0.32 & .192 & .36 & .1024 \\
\hline .74 & 0.4 & .296 & 0.5476 & .16 \\
\hline 1,1 & .89 & .979 & 1.21 & .7921 \\
\hline 0.8 & 0.6 & 0.48 & 0.64 & .36 \\
\hline 1,1 & 0.69 & 0.759 & 1.21 & 0.4761 \\
\hline 1,3 & 1.19 & 1,547 & 1.69 & 1,4161 \\
\hline 0.7 & .36 & 0.252 & 0.49 & 0.1296 \\
\hline 0.8 & 0.42 & 0.336 & 0.64 & 0.1764 \\
\hline 0.6 & 0.25 & .15 & .36 & 0.0625 \\
\hline 0.8 & 0.25 & 0.2 & 0.64 & 0.0625 \\
\hline 0.8 & 0.53 & 0.424 & 0.64 & 0.2809 \\
\hline .73 & 0.45 & 0.3285 & 0.5329 & 0.2025 \\
\hline 1 & 0.9 & 0.9 & 1 & .81 \\
\hline 1.62 & 1.07 & 1.7334 & 2,6244 & 1.1449 \\
\hline 0.9 & 0.55 & 0.495 & .81 & 0.3025 \\
\hline 1 & .83 & .83 & 1 & .6889 \\
\hline 1 & 0.69 & 0.69 & 1 & 0.4761 \\
\hline .74 & .19 & 0.1406 & 0.5476 & 0.0361 \\
\hline 0.85 & 0.44 & .374 & .7225 & 0.1936 \\
\hline 1,1 & .94 & 1,034 & 1.21 & .8836 \\
\hline 0.8 & 0.25 & 0.2 & 0.64 & 0.0625 \\
\hline 1 & 0.7 & 0.7 & 1 & 0.49 \\
\hline .76 & 0.48 & .3648 & 0.5776 & 0.2304 \\
\hline 1,1 & 0.9 & .99 & 1.21 & .81 \\
\hline .78 & 0.51 & 0.3978 & 0.6084 & 0.2601 \\
\hline .86 & 0.31 & 0.2666 & 0.7396 & 0.0961 \\
\hline 0.8 & 0.5 & 0.4 & 0.64 & 0.25 \\
\hline 0.68 & 0.23 & .1564 & .4624 & 0.0529 \\
\hline 0.8 & 0.4 & 0.32 & 0.64 & .16 \\
\hline 1.05 & 0.88 & 0.924 & 1,1025 & .7744 \\
\hline 0.9 & 0.61 & 0.549 & .81 & .3721 \\
\hline .67 & 0.45 & 0.3015 & 0.4489 & 0.2025 \\
\hline 0.8 & 0.25 & 0.2 & 0.64 & 0.0625 \\
\hline .89 & 0.66 & 0.5874 & .7921 & 0.4356 \\
\hline 0.8 & 0.6 & 0.48 & 0.64 & .36 \\
\hline 31.87 & 20.31 & 19,536 & 29,6365 & 13,7603 \\
\hline
\end{tabular}


Calculation of the correlation between the variables X1 and X2 variables. Based on the table above, the numbers can be obtained through the following statistics:

\section{Validity test}

Validity test is carried out to determine the level of reliability and validity of the compressor compressor suction pressure variable (X1) to the tank pressure (X2) used the same validity formula with the correlation coefficient formula as follows.

$$
\begin{aligned}
& r_{x 1 x 2}=\frac{n \cdot \sum X_{1} X_{2}-\sum X_{1} \cdot \sum X_{2}}{\sqrt{n \cdot \sum X_{1}^{2}-\left(\sum X_{1}\right)^{2}} \sqrt{n \cdot \sum X_{2}^{2}-\left(\sum X_{2}\right)^{2}}} \cdot \\
& r_{x 1 x 2}=\frac{(36)(19,536)-(31,87)(20,31)}{\sqrt{(36) 29,6365-(31,87)^{2}} \cdot \sqrt{(36) 13,7603-(20,31)^{2}}} \\
& r_{x 1 x 2}=\frac{703,296-646,2797}{\sqrt{1.066,914-1 \cdot 015,6969} \cdot \sqrt{495,3708-412,4961}} \\
& r_{x 1 x 2}=\frac{57,0163}{\sqrt{51,2171} \cdot \sqrt{82,8747}} \\
& r_{x 1 x 2}=\frac{57,0163}{(7,15)(9,10)} \\
& r_{x 1 x 2}=\frac{57,0163}{65,065} \\
& r_{x 1 x 2}=0,86
\end{aligned}
$$

Can be concluded :

If $\mathrm{r}$ arithmetic $<\mathrm{r}$ table, the research statement is invalid.

If $r$ count $>r$ table, then the research statement is said to be valid.

To prove the validity test of the Cargo Compressor Suction Pressure variable (X1) to the Tank Pressure (X2) according to the calculation obtained on the correlation coefficient of $(0.86)$, so that the validity number of $(0.86)$ is to do is to find a count that is based on the criteria with the provisions of df (degree of freedom) with the value of $n$ (number of samples) known 36 (twelve), $\mathrm{df}=\mathrm{n}-2$ then it becomes $\mathrm{df}=36-2$ that is 34 then compared to rtable at $\alpha=0.05$; then it is 0.576 (from rtable).

Then, the results obtained are $r 3=r$ count $=0.86$, because $r$ count $>r$ table $(0.86>0.339)$. So it can be concluded that the variable Pressure Cargo Compressor Suction (X1) against Tank Pressure (X2) is declared valid

\section{Reliability Test}

In this study, the authors did not use the reliability test because the data I used were secondary data not based on a research questionnaire.

\section{Regression Correlation Coefficient Analysis}


To find out the strength or weakness of the relationship between variable X1 and variable X2, then this analysis will find out the value of $r$ (correlation coefficient), namely by the formula:

Regression Correlation Coefficient Formula $=$ Validity Test Formula

$$
\begin{aligned}
r_{x 1 x 2} & =\frac{n \cdot \sum X_{1} X_{2}-\sum X_{1} \cdot \sum X_{2}}{\sqrt{n \cdot \sum X_{1}^{2}-\left(\sum X_{1}\right)^{2}} \sqrt{n \cdot \sum X_{2}^{2}-\left(\sum X_{2}\right)^{2}} .} \\
r_{x 1 x 2} & =0,86
\end{aligned}
$$

From the above calculation, the correlation coefficient figure of $(0.86)$ is obtained, it means that there is a very strong influence between Compressor Cargo Suction Pressure on Tank Pressure. If the correlation results are positive, it can be interpreted if the Compressor Cargo Suction Pressure increases, it will also increase the Tank Pressure. Vice versa, if there is a decrease in Compressor Cargo Suction Pressure it will reduce the Tank Pressure

\section{Determination Coefficient Analysis (KD = R2)}

Analysis of the coefficient of determination is to find out how much the contribution of the Cargo Compressor Suction Pressure (X1) toTank Pressure (X2) used the coefficient of determination formula as follows:

$\mathrm{KD}=\mathrm{r} 2 \times 100 \%$

$\mathrm{BC}=(0.86) 2 \times 100 \%$

$\mathrm{BC}=0.73 \times 100 \%$

$\mathrm{KD}=73 \%$

Information :

$\mathrm{KD}=$ Coefficient of determination

rxy $\quad=$ Correlation coefficient $\mathrm{X}$ and $\mathrm{Y}$

With a regression line value $(\mathrm{r} 2=0.73)$ close to 1 , it is said to be feasible to use. Then the coefficient of determination is $73 \%$ shows that the value is worth continuing to predict using a regression formula where $73 \%$ of the Compressor Cargo Suction Pressure affects the Tank Pressure and $27 \%$ by other factors.

\section{Hypothesis testing}

Hypothesis testing about the correlation coefficient. Judging from the calculation of the correlation coefficient, determination and regression lines, then the hypothesis test can be done to determine the effect of Compressor Cargo Suction Pressure on Tank Pressure on LPG / C Griya Borneo Vessels.

Partial Correlation Coefficient Test (T Test)

Hypothesis tests used by the authors are as follows: 
If tcount <ttable, then Ho is accepted and H3 is rejected, meaning that there is no significant relationship between Compressor Cargo Suction Pressure to Tank Pressure on the Griya Borneo LPG / C.

If tcount> ttable, then $\mathrm{Ho}$ is rejected and $\mathrm{H} 3$ is accepted, meaning that there is a significant relationship between Compressor Cargo Suction Pressure and Tank Pressure on Griya Borneo LPG / C. To prove that $\mathrm{H} 3$ is accepted or rejected, then what is done is to look for $\mathrm{t}$ arithmetic by step in entering the value (r) into the formula, the value of $n$ (number of samples) is known 36 (thirty six), then compared to the table at $\alpha=0.05$; $\mathrm{df}=\mathrm{nk}$ where $\mathrm{k}$ is the number of variables (free + bound) and $\mathrm{n}$ is the number of observations / samples forming the regression. So $\mathrm{df}=36-2=34$ is 1.69092 (from the table).

$\mathrm{t} 3=\mathrm{t}$ count

$\mathrm{t} 3=\frac{r \sqrt{n-2}}{\sqrt{1-(r)^{2}}}=\frac{(0.86) \sqrt{36-2}}{\sqrt{1-\left(0,86^{2}\right)}}=\frac{(0,86) \sqrt{34}}{\sqrt{1-0,73}}=\frac{(0,86) \cdot 5,83}{\sqrt{0,27}}=\frac{5,0138}{0,519}=9,66$

Then, the results obtained are $\mathrm{t} 3=$ tcount $=9.66$, because tcount $>$ ttable $(9.66>1.69092)$. So Ho is rejected and $\mathrm{H} 3$ is accepted, meaning that there is a significant relationship between X1 and X2. So there is a significant relationship between Compressor Cargo Suction Pressure and Tank Pressure on LPG / C Griya Borneo.

1) Simultaneous Correlation Coefficient Test (Test F)

Hypothesis tests used by the authors are as follows:

If the count is <ftabel, then Ho is accepted and H3 is rejected, meaning that there is no significant relationship between the Compressor Cargo Suction Pressure to the Tank Pressure on the Griya Borneo LPG / C.

If the count is > ftabel, then Ho is rejected and $\mathrm{H} 3$ is accepted, meaning that there is a significant relationship between the Compressor Cargo Suction Pressure to the Tank Pressure on the Griya Borneo LPG / C.

To prove that $\mathrm{H} 3$ is accepted or rejected, what is done is to look for fcount, namely by entering the value (r) into the formula, the value of $n$ (number of samples), degree of freedom (df) for the numerator or known as df1 with the symbol N1, degree of freedom (df) for the denominator, also known as df1with the symbol N2then compared ftabel at $\alpha=0.05$; df1 $=\mathrm{k}$ 1 ; $\mathrm{df} 2=\mathrm{nk}$ where $\mathrm{k}$ is the number of variables (free + bound) and $\mathrm{n}$ is the number of observations / samples forming the regression. Countable :

$$
\begin{gathered}
\text { df1 }=\mathrm{k}-1 \\
=2-1=1 \\
\text { df2 }=\mathrm{n}-\mathrm{k} \\
=36-2=34
\end{gathered}
$$

So that $\mathrm{N} 1=1$ and $\mathrm{N} 2=10$ then ftabel $=4.13$.

$\mathrm{f} 3$ = fcount

fcount

$$
\begin{aligned}
& =\frac{r^{2} \bar{k}}{1-r^{2} \overline{n-k-1}} \\
& =\frac{(0,86)^{2} / 2}{1-(0,86)^{2} \overline{36-2-1}}=\frac{0,73 / 2}{1-0,73 / 33}=\frac{0,365}{0,008} \\
& =45,625
\end{aligned}
$$

Then, the results obtained are $\mathrm{f} 3=$ fcount $=54.28$, because fcount $>$ ftabel $(45.625>4.13)$. So Ho is rejected and H3 is accepted, meaning that there is a significant relationship between X1 
and X2. So there is a significant relationship between Compressor Cargo Suction Pressure and Tank Pressure on LPG / C Griya Borneo.

\section{Correlation between the Compressor Cargo Suction Pressure (X1) and Tank Pressure (X2) and the Length of the Reliquefaction Process (Y)}

Table 8 Results of Compressor Cargo Suction Pressure Analysis (X1), Tank Pressure (X2) and Length of Reliquefaction Process (Y)

\begin{tabular}{|c|c|c|c|c|}
\hline Voyage & $\mathrm{X} 1$ & $\mathrm{X} 2$ & $\mathrm{Y}$ & (X1) 2 \\
\hline Voyage 1 & 0.9 & 0.62 & 12 & .81 \\
\hline Voyage 2 & 0.6 & 0.32 & 6 & .36 \\
\hline Voyage 3 & .74 & 0.4 & 8 & 0.5476 \\
\hline Voyage 4 & 1,1 & .89 & 20 & 1.21 \\
\hline Voyage 5 & 0.8 & 0.6 & 13 & 0.64 \\
\hline Voyage 6 & 1,1 & 0.69 & 14 & 1.21 \\
\hline Voyage 7 & 1,3 & 1.19 & 25 & 1.69 \\
\hline Voyage 8 & 0.7 & .36 & 7 & 0.49 \\
\hline Voyage 9 & 0.8 & 0.42 & 10 & 0.64 \\
\hline Voyage 10 & 0.6 & 0.25 & 6 & .36 \\
\hline Voyage 11 & 0.8 & 0.25 & 8 & 0.64 \\
\hline Voyage 12 & 0.8 & 0.53 & 11 & 0.64 \\
\hline Voyage 13 & .73 & 0.45 & 7 & 0.5329 \\
\hline Voyage 14 & 1 & 0.9 & 18 & 1 \\
\hline Voyage 15 & 1.62 & 1.07 & 30 & 2,6244 \\
\hline Voyage 16 & 0.9 & 0.55 & 11 & .81 \\
\hline Voyage 17 & 1 & .83 & 19 & 1 \\
\hline Voyage 18 & 1 & 0.69 & 14 & 1 \\
\hline Voyage 19 & .74 & .19 & 6 & 0.5476 \\
\hline Voyage 20 & 0.85 & 0.44 & 10 & .7225 \\
\hline Voyage 21 & 1,1 & .94 & 21 & 1.21 \\
\hline Voyage 22 & 0.8 & 0.25 & 8 & 0.64 \\
\hline Voyage 23 & 1 & 0.7 & 18 & 1 \\
\hline Voyage 24 & .76 & 0.48 & 8 & 0.5776 \\
\hline Voyage 25 & 1,1 & 0.9 & 18 & 1.21 \\
\hline Voyage 26 & .78 & 0.51 & 10 & 0.6084 \\
\hline Voyage 27 & .86 & 0.31 & 10 & 0.7396 \\
\hline Voyage 28 & 0.8 & 0.5 & 12 & 0.64 \\
\hline Voyage 29 & 0.68 & 0.23 & 5 & .4624 \\
\hline Voyage 30 & 0.8 & 0.4 & 10 & 0.64 \\
\hline Voyage 31 & 1.05 & 0.88 & 18 & 1,1025 \\
\hline Voyage 32 & 0.9 & 0.61 & 12 & .81 \\
\hline Voyage 33 & .67 & 0.45 & 7 & 0.4489 \\
\hline Voyage 34 & 0.8 & 0.25 & 8 & 0.64 \\
\hline Voyage 35 & .89 & 0.66 & 13 & .7921 \\
\hline Voyage 36 & 0.8 & 0.6 & 12 & 0.64 \\
\hline Total & 31.87 & 20.31 & 445 & 29,6365 \\
\hline$(\mathrm{X} 2) 2$ & Y2 & $\mathrm{X} 1 \mathrm{X} 2$ & $\mathrm{X} 1 \mathrm{Y}$ & $\mathrm{X} 2 \mathrm{Y}$ \\
\hline 0.3844 & 144 & 0.558 & 10.8 & 7.44 \\
\hline
\end{tabular}




\begin{tabular}{|c|c|c|c|c|}
\hline .1024 & 36 & .192 & 3,6 & 1.92 \\
\hline .16 & 64 & .296 & 5.92 & 3,2 \\
\hline .7921 & 400 & .979 & 22 & 17.8 \\
\hline .36 & 169 & 0.48 & 10.4 & 7.8 \\
\hline 0.4761 & 196 & 0.759 & 15.4 & 9.66 \\
\hline 1,4161 & 625 & 1,547 & 32.5 & 29.75 \\
\hline 0.1296 & 49 & 0.252 & 4.9 & 2.52 \\
\hline 0.1764 & 100 & 0.336 & 8 & 4.2 \\
\hline 0.0625 & 36 & .15 & 3,6 & 1.5 \\
\hline 0.0625 & 64 & 0.2 & 6,4 & 2 \\
\hline 0.2809 & 121 & 0.424 & 8.8 & 5.83 \\
\hline 0.2025 & 49 & 0.3285 & 5,11 & 3.15 \\
\hline .81 & 324 & 0.9 & 18 & 16.2 \\
\hline 1.1449 & 900 & 1.7334 & 48.6 & 32.1 \\
\hline 0.3025 & 121 & 0.495 & 9.9 & 6.05 \\
\hline .6889 & 361 & .83 & 19 & 15.77 \\
\hline 0.4761 & 196 & 0.69 & 14 & 9.66 \\
\hline 0.0361 & 36 & 0.1406 & 4.44 & 1.14 \\
\hline 0.1936 & 100 & .374 & 8.5 & 4,4 \\
\hline .8836 & 441 & 1,034 & 23.1 & 19.74 \\
\hline 0.0625 & 64 & 0.2 & 6,4 & 2 \\
\hline 0.49 & 324 & 0.7 & 18 & 12.6 \\
\hline 0.2304 & 64 & .3648 & 6.08 & 3.84 \\
\hline .81 & 324 & .99 & 19.8 & 16.2 \\
\hline 0.2601 & 100 & 0.3978 & 7.8 & 5.1 \\
\hline 0.0961 & 100 & 0.2666 & 8.6 & 3.1 \\
\hline 0.25 & 144 & 0.4 & 9.6 & 6 \\
\hline 0.0529 & 25 & .1564 & 3,4 & 1.15 \\
\hline .16 & 100 & 0.32 & 8 & 4 \\
\hline .7744 & 324 & 0.924 & 18.9 & 15.84 \\
\hline .3721 & 144 & 0.549 & 10.8 & 7.32 \\
\hline 0.2025 & 49 & 0.3015 & 4.69 & 3.15 \\
\hline 0.0625 & 64 & 0.2 & 6,4 & 2 \\
\hline 0.4356 & 169 & 0.5874 & 11.57 & 8.58 \\
\hline .36 & 144 & 0.48 & 9.6 & 7.2 \\
\hline 13,7603 & 6671 & 19,536 & 432.61 & 299.91 \\
\hline
\end{tabular}

\section{Validity test}

Validity test is carried out to determine the level of reliability and validity of the Cargo Compressor Suction Pressure variable (X1) on the Length of the Reliquefaction Process (Y), using the same validity formula as the correlation coefficient formula as follows.

$$
\begin{aligned}
& r_{x 1 y}=0,94 ; ; r_{x 2 y}=0,94 r_{x 1 x 2}=0,86 \\
& \operatorname{ryx} 1 x 2=\sqrt{\frac{r^{2} x_{1} y+r^{2} x_{2} y-2 r x_{1} y r x_{2} y r x_{1} x_{2}}{1-r^{2} x 1 x 2}} \\
& \operatorname{ryx} 1 x 2=\sqrt{\frac{(0,94)^{2}+(0,94)^{2}-2(0,94)(0,94)(0,86)}{1-(0,86)^{2}}}
\end{aligned}
$$




$$
\begin{aligned}
& \operatorname{ryx} 1 \times 2=\sqrt{\frac{(0,88)+(0,88)-1,52}{1-(0,74)}} \\
& \operatorname{ryx} 1 \times 2=\sqrt{\frac{1,76-1,51}{0,26}} \\
& \operatorname{ryx} 1 \times 2=\sqrt{\frac{0,25}{0,26}} \\
& \operatorname{ryx} 1 \times 2=\sqrt{0,96} \\
& \operatorname{ryx} 1 \times 2=0.97
\end{aligned}
$$

Can be concluded :

If $\mathrm{r}$ arithmetic $<\mathrm{r}$ table, the research statement is invalid.

If $r$ count $>r$ table, then the research statement is said to be valid.

To prove the validity test of the Cargo Compressor Suction Pressure (X1) and Tank Pressure (X2) against the Length of the Reliquefaction Process (Y) according to the calculation obtained on the correlation coefficient number of (0.95), so the validity number of (0.95) then done is to look for $r$ count that is based on the criteria with the provisions of $\mathrm{df}$ (degree of freedom) with the value of $\mathrm{n}$ (number of samples) known 36 (twelve), $\mathrm{df}=\mathrm{n}-2$ then it becomes $\mathrm{df}=36-2$ that is 34 then compared to rtable on $\alpha=0.05$; then it is 0.339 (from rtable).

Then, the results obtained are $r 4=r$ count $=0.97$, because $r$ count $>r$ table $(0.97>0.339)$. So it can be concluded that the Compressor Cargo Suction Pressure (X1) and Tank Pressure (X2) against the Length of the Reliquefaction Process (Y) are declared valid.

\section{Reliability Test}

In this study, the authors did not use the reliability test because the data I used were secondary data not based on a research questionnaire.

\section{Equation of Multiple Linear Regression}

To find out how big is the correlation between the Cargo Compressor Suction Pressure (X1) and Tank Pressure (X2) on the Length of the Reliquefaction Process (Y) using the Multiple Linear Regression Equation method. Where in general, the data observed by Y are influenced by variables $\mathrm{X} 1$ and $\mathrm{X} 2$, so the formula of multiple linear regression is:

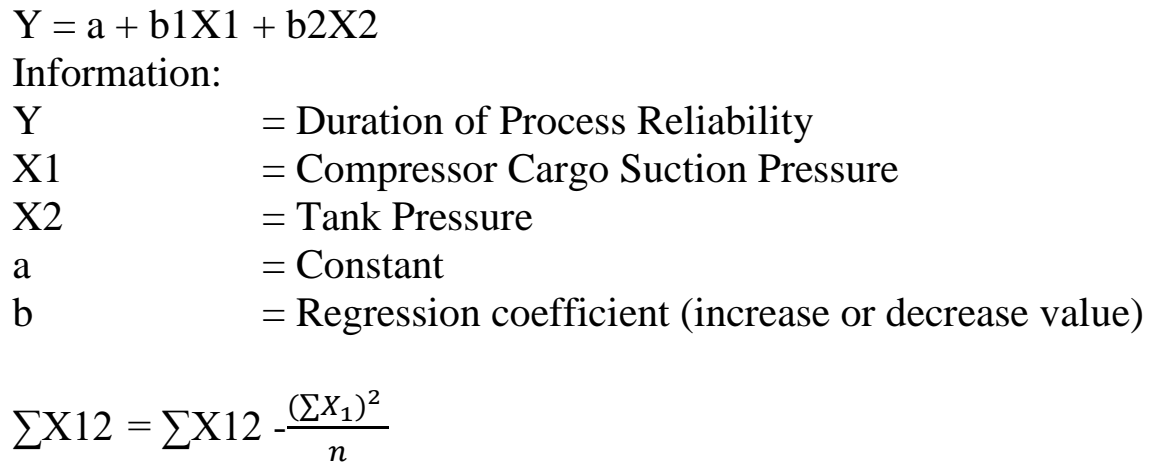




$$
\begin{aligned}
& =29,6365-\frac{(31,87)^{2}}{36} \\
& =29,6365-\frac{1.015,69}{36} \\
& =29,6365-28.21 \\
& =1.4265 \\
& \sum \mathrm{X} 22=\sum \mathrm{X} 22-\frac{\left(\sum X_{2}\right)^{2}}{n} \\
& =13,7603-\frac{(20,31)^{2}}{36} \\
& =13,7603-\frac{(412,4961)}{36} \\
& =13,7603-11,458 \\
& =2.3023 \\
& \sum Y 2=\sum Y 2-\frac{\left(\sum Y\right)^{2}}{n} \\
& =6,671-\frac{(445)^{2}}{36} \\
& =6,671-\frac{(198.025)}{36} \\
& =6,671-5,500,694 \\
& =1,170,306 \\
& \sum \mathrm{X} 1 \mathrm{Y}=\sum \mathrm{X}_{1} \mathrm{Y}-\frac{\left(\sum X_{1} \cdot \sum Y\right)}{n} \\
& \begin{aligned}
& n \\
= & 432.61-\frac{(31,87)(445)}{36} \\
= & 432.61-393.94 \\
= & 38.67
\end{aligned} \\
& \sum \mathrm{X} 2 \mathrm{Y}=\sum \mathrm{X}_{2} \mathrm{Y}-\frac{\left(\sum X_{2} \cdot \sum Y\right)}{n} \\
& =299.91-\frac{(20,31)(445)}{36} \\
& =299.91-251,054 \\
& =48,856 \\
& \sum \mathrm{X} 1 \mathrm{X} 2=\sum \mathrm{X} 1 \mathrm{X} 2-\frac{\left(\sum X_{1} \cdot \sum X_{2}\right)}{n} \\
& =19,536-\frac{(31,87)(20,31)}{36} \\
& =19,536-17,979 \\
& =1,557
\end{aligned}
$$

So, the values of b1, b2 and a are as follows:

$$
\begin{aligned}
\text { b1 } & =\frac{\left[\left(\sum X_{2}^{2} \cdot \sum X_{1} Y\right)-\left(\sum X_{2} Y \cdot \sum X_{1} X_{2}\right)\right]}{\left[\left(\sum X_{1}{ }^{2} \cdot \sum X_{2}{ }^{2}\right)-\left(\sum X_{1} X_{2}\right)^{2}\right]} \\
& =\frac{[(2,3023)(38,67)-(48,856)(1,557)]}{\left[(1,4265)(2,3023)-(1,557)^{2}\right]} \\
& =\frac{[(89,029)-(76,068)]}{[(3,284)-(2,4242)]} \\
& =\frac{[(12,961)]}{[(0,8598)]} \\
& =15.07 \\
\text { b2 } & =\frac{\left[\left(\sum X_{1}{ }^{2} \cdot \sum X_{2} Y\right)-\left(\sum X_{1} Y \cdot \sum X_{1} X_{2}\right)\right]}{\left[\left(\sum X_{1}{ }^{2} \cdot \sum X_{2}{ }^{2}\right)-\left(\sum X_{1} X_{2}\right)^{2}\right]}
\end{aligned}
$$




$$
\begin{aligned}
& =\frac{[(1,4265)(48,856)-(38,67)(1,557)]}{\left[(1,4265)(2,3023)-(1,557)^{2}\right]} \\
& =\frac{[(69,693)-(60,209)]}{[(3,284)-(2,4242)]} \\
& =\frac{[(9,484)]}{[(0,8598)]} \\
& =11.03 \\
& =\frac{\sum Y-\left(b_{1} \sum X_{1}\right)-\left(b_{2} \sum X_{2}\right)}{n} \\
& =\frac{445-(15,07 \times 31,87)-(11,03 \times 20,31)}{36} \\
& =\frac{445-(480,28)-(224,01)}{36} \\
& =\frac{259,29}{36} \\
& =-7.2
\end{aligned}
$$

So, the multiple linear regression equation is

$\mathrm{Y}=\mathrm{a}+\mathrm{b} 1 \mathrm{X} 1+\mathrm{b} 2 \mathrm{X} 2$

$\mathrm{Y}=-7.2+15.07 \mathrm{X} 1+11.03 \mathrm{X} 2$

\section{Interpretation of Correlation Coefficients}

1) Value of $\mathrm{a}=-7.2$; meaning that if the Compressor Cargo Suction Pressure (X1) and Tank Pressure (X2) value is 0, then the Reliquefaction (Y) Process Duration value is (-7.2)\% or there is no Reliquefaction.

2) Value of $\mathrm{b} 1=15.07$; meaning that if the Tank Pressure is considered constant and the Compressor Cargo Suction Pressure increases by one percent, the Length of the Reliquefaction Process will increase by 15.07 units. The positive value coefficient means that there is a positive relationship between the Compressor Cargo Suction Pressure and the Length of the Reliquefaction Process, the greater the Compressor Cargo Suction Pressure, the longer the Reliquefaction Process.

3) Value b2 $=0.02$; meaning that if the Compressor Cargo Suction Pressure is considered constant and the Tank Pressure increases by one percent then the Length of the Reliquefaction Process will increase by 11.03 units. The positive value coefficient means that there is a positive relationship between the Tank Pressure and the Length of the Reliquefaction Process, the higher the Tank Pressure the longer the Reliquefaction Process.

\section{Calculate the Multiple Regression Correlation Coefficient}

To find out the strength or weakness of the relationship between the variables X1 and X2 to the variable $\mathrm{Y}$ then this analysis will know the value of $\mathrm{r}$ (correlation coefficient), namely by the formula:

Regression Correlation Coefficient Formula $=$ Validity Test Formula

$\mathrm{r}_{\mathrm{x} 1 \mathrm{y}}=0,94 ; ; \mathrm{r}_{\mathrm{x} 2 \mathrm{y}}=0,94 \mathrm{r}_{\mathrm{x} 1 \mathrm{x} 2}=0,86$

$\operatorname{ryx} 1 \times 2=\sqrt{\frac{r^{2} x_{1} y+r^{2} x_{2} y-2 r_{1} y r_{2} y r_{1} x_{2}}{1-r^{2} x_{1} x_{2}}}$

$\operatorname{ryx} 1 \times 2=0.97$ 
From the above calculation, the correlation coefficient figure is (0.97), it means that there is a very strong influence between Compressor Cargo Suction Pressure (X1) and Tank Pressure (X2) on the Length of the Reliquefaction Process (Y).

If the results of the correlation are positive, it can be interpreted if the Compressor Cargo Suction Pressure and Tank Pressure increase, it will increase the time of the Reliquefaction Process. Vice versa, if there is a decrease in compressor Cargo Suction Pressure and Tank Pressure, the time needed for the Reliquefaction Process will be shorter.

\section{Calculate the coefficient of determination}

Analysis of the coefficient of determination is to find out how much the contribution of the Cargo Compressor Suction Pressure (X1) and Tank Pressure (X2) to the Length of the Reliquefaction Process $(\mathrm{Y})$ used the determination coefficient formula as follows:

r2

r2

r2

r2

r2

$$
=\frac{\left(\mathrm{b}_{1} \sum \mathrm{X}_{1} \mathrm{Y}\right)+\left(\mathrm{b}_{2} \sum \mathrm{X}_{2} \mathrm{Y}\right)}{\sum \mathrm{Y}^{2}}
$$$$
=\frac{(15,07 \cdot 38,67)+(11,03 \cdot 48,856)}{1170,306}
$$$$
=\frac{(582,75)+(538,88)}{1170,306}
$$$$
=\frac{1121,63}{1170,306}
$$$$
=0.97
$$

$\mathrm{KD}=\mathrm{r} 2 \times 100 \%$

$\mathrm{KD}=(0.97) \times 100 \%$

$\mathrm{KD}=94 \%$

By getting the $\mathrm{KD}$ value $=94 \%$ indicates that the magnitude of the coefficient of determination between Compressor Cargo Suction Pressure and Tank Pressure on the Length of the Reliquefaction Process is $94 \%$. This means that about $94 \%$ between Compressor Cargo Suction Pressure (X1) and Tank Pressure (X2) can explain the Length of the Reliquefaction Process (Y).

\section{Hypothesis testing}

Hypothesis testing about the correlation coefficient. Judging from the calculation of the correlation coefficient, determination and regression lines, the hypothesis test can be done to determine the influence of Compressor Cargo Suction Pressure and Tank Pressure on the Length of the Reliquefaction Process in the LPG / C Griya Borneo ship.

Hypothesis testing used in multiple linear regression by the author is to calculate tcount and fcount is as follows.

1) Partial Correlation Coefficient Test (T Test)

Hypothesis tests used by the authors are as follows:

If tcount <ttable, then Ho is accepted and H4 is rejected, meaning that there is no significant relationship between Compressor Cargo Suction Pressure and Tank Pressure on the Length of the Reliquefaction Process on LPG / C Griya Borneo

If tcount> ttable then Ho is rejected and H4 is accepted, meaning that there is a significant relationship between Compressor Cargo Suction Pressure and Tank Pressure on the Length of the Reliquefaction Process in LPG / C Griya Borneo ships. 
To prove that $\mathrm{H} 4$ is accepted or rejected, what is done is to look for tcount, namely by entering the value (r) into the formula, the value of n (number of samples) is known 36 (thirty six), then compared to the table at $\alpha=0.05$; $\mathrm{df}=\mathrm{nk}$ where $\mathrm{k}$ is the number of variables (free + bound) and $\mathrm{n}$ is the number of observations / samples forming the regression. So $\mathrm{df}=36-3=33$ is 1.6923 (from the table).

$\mathrm{t} 4=\mathrm{t}$ count

$\mathrm{t} 4=\frac{\mathrm{r} \sqrt{\mathrm{n}-2}}{\sqrt{1-(\mathrm{r})^{2}}}=\frac{(0.95) \sqrt{36-2}}{\sqrt{1-\left(0,95^{2}\right)}}=\frac{(0.95) \sqrt{34}}{\sqrt{1-0,90}}=\frac{(0,95) .5,83}{\sqrt{0,10}}=\frac{5,53}{0,31}=17,83$

Then, the results obtained are $\mathrm{t} 4=\mathrm{t}=17.83$, because $\mathrm{t}>\mathrm{t}$ table (17.83>1.6923). So Ho is rejected and $\mathrm{H} 4$ is accepted, meaning that there is a significant relationship between $\mathrm{X} 1, \mathrm{X} 2$ and Y. So that there is a significant relationship between Compressor Cargo Suction Pressure and Tank Pressure on the Length of the Reliquefaction Process on LPG / C Griya Borneo.

2) Simultaneous Correlation Coefficient Test (Test F)

Hypothesis tests used by the authors are as follows:

If the count is <ftabel, then Ho is accepted and $\mathrm{H} 4$ is rejected, meaning that there is no significant relationship between Compressor Cargo Suction Pressure and Tank Pressure on the Length of the Reliquefaction Process on the LPG / C Griya Borneo ship.

If the count is> ftabel, then Ho is rejected and $\mathrm{H} 4$ is accepted, meaning that there is a significant relationship between Compressor Cargo Suction Pressure and Tank Pressure on the Length of the Reliquefaction Process in the LPG / C Griya Borneo ship.

To prove that $\mathrm{H} 4$ is accepted or rejected, what is done is to find a fcount that is by entering the value (r) into the formula, the value of $n$ (number of samples), degree of freedom (df) for the numerator or known as df1 with the symbol N1, degree of freedom (df) for the denominator, also known as df1with the symbol N2then compared ftabel at $\alpha=0.05$; df1 $=\mathrm{k}-1$; df $2=\mathrm{nk}$ where $\mathrm{k}$ is the number of variables (free + bound) and $\mathrm{n}$ is the number of observations / samples forming the regression. Countable :

$$
\begin{gathered}
\text { df1 }=\mathrm{k}-1 \\
=3-1=2 \\
\mathrm{df2}=\mathrm{n}-\mathrm{k} \\
=36-3=33
\end{gathered}
$$

So that $\mathrm{N} 1=2$ and $\mathrm{N} 2=33$ then ftabel $=3.34$

$\mathrm{f} 4=$ fcount

fcount $\quad=\frac{\mathrm{r}^{2} / \mathrm{k}}{1-\mathrm{r}^{2} /(\mathrm{n}-\mathrm{k}-1)} \frac{(0,95)^{2} / 2}{1-(0,95)^{2} /(36-3-1)}=\frac{0,90 / 2}{1-0,90 / 32}=\frac{0,45}{0,003}=150$

Then, the result obtained is $f 4=$ fcount $=150$, because fcount $>$ ftabel (150> 3.34). So Ho is rejected and $\mathrm{H} 4$ is accepted, meaning that there is a significant relationship between $\mathrm{X} 1, \mathrm{X} 2$ and Y. So that there is a significant relationship between Compressor Cargo Suction Pressure and Tank Pressure on the Length of the Reliquefaction Process on LPG / C Griya Borneo

\section{CONCLUSION}

Based on the results of research and discussion of regression analysis and correlation coefficients, coefficient of determination, validity test, and hypothesis testing between compressor compressor suction pressure and tank pressure on the duration of the reliquefaction process on the LPG / C Griya Borneo ship in August 2018 to August 2019, then conclusions can be drawn namely:

1. In the correlation of the Compressor Cargo Suction Pressure (X1) to the Length of the Reliquefaction Process (Y) on the LPG / C Griya Borneo ship, the correlation coefficient data 
of 0.94 () shows that there is a positive and strong correlation effect. Then obtained $\mathrm{r} 2=0.88$, proving that the linear regression is feasible and the coefficient of determination of $88 \%$ (KD $=88 \%$ ) states that the Compressor Cargo Suction Pressure affects the Length of the Reliquefaction Process. Then in tcount $=15.82(15.82>1.69092)$ and fcount $=122.2(122.2>$ 4.13), where if tcount $>$ ttable and fcount $>$ ftabel then there is a significant relationship between variables X1 and Y.r. $\mathrm{r}_{\mathrm{x} 1 \mathrm{y}}=0,94$

To speed up the reliquefaction process to $90 \%$, it can be done by keeping the compressors' cargo suction pressure stable. Maintain the valve so that the compression remains maximum and the suction valve is not easily damaged. Then you must apply the maintenance management procedure properly and carry out maintenance and replacement of the compressor suction valve.

2. In the correlation between the tank pressure (X2) and the duration of the reliquefaction (Y) on the LPG / C Griya Borneo ship, the correlation coefficient data is 0.94 (proving that there is a positive and strong correlation effect. Then $\mathrm{r} 2=0.88$, prove that this linear regression is feasible and the coefficient of determination of $88 \%(\mathrm{KD}=88 \%)$ states that tank pressure affects the duration of the reliquefaction process, then in $t=15.82(15.82>1.69092)$ and fcount $=122.2(122.2>4.13)$, where if tcount $>$ ttable and fcount $>$ ftabel then there is a significant relationship between variables $\mathrm{X} 2$ and $\mathrm{Y} . \mathrm{r}_{\mathrm{x} 2 \mathrm{y}}=0,94$ )

To speed up the process of reliquefaction to reach $90 \%$, it can be done by maintaining tank pressure so as not to reach high numbers. Maintaining tank pressure can be done by maintaining the tank temperature so as not to reach high numbers. Keeping the tank temperature can be done by the officer who can check the tank temperature periodically and write it in the cargo log book so that the Chief Officer can control the tank temperature and if the temperature has reached a very high number so that it is immediately reported to the Chief Officer and the Chief Officer will take action.

3. This linear regression is feasible and a coefficient of determination of $88 \%(\mathrm{KD}=88 \%)$ states that tank pressure affects the duration of the reliquefaction process. Then in tcount $=15.82$ $(15.82>1.69092)$ and fcount $=122.2(122.2>4.13)$, where if tcount $>$ ttable and fcount $>$ ftabel then there is a significant relationship between variables $\mathrm{X} 2$ and $\mathrm{Y}$.

To speed up the process of reliquefaction to reach $90 \%$, it can be done by maintaining tank pressure so as not to reach high numbers. Maintaining tank pressure can be done by maintaining the tank temperature so as not to reach high numbers. Keeping the tank temperature can be done by the officer who can check the tank temperature periodically and write it in the cargo log book so that the Chief Officer can control the tank temperature and if the temperature has reached a very high number so that it is immediately reported to the Chief Officer and the Chief Officer will take action.

4. In the correlation of compressor compressor suction pressure (X1) to tank pressure (X2) in LPG / C Griya Borneo ship, obtained correlation coefficient data of 0.86 () proves that there is a positive and very strong correlation effect. Then obtained $\mathrm{r} 2=0.73$, proving that this linear regression is feasible and the coefficient of determination of $73 \%(\mathrm{KD}=73 \%)$ states that the compressor cargo pressure affects the tank pressure. Then in tcount $=9.66(9.66>1.69092)$ and fcount $=45.625$ (45.625> 4.13), where if tcount $>$ ttable and fcount $>$ ftabel then there is a significant relationship between variables $\mathrm{X} 1$ and $\mathrm{X} 2 \cdot \mathrm{r}_{\mathrm{x} 1 \mathrm{x} 2}=0,86$

If the compressor compressor has high suction pressure, it is caused by a large tank pressure. If the vapor in the tank is large, the compressor cargo suction pressure is also large. So it needs 
to be controlled so that the tank pressure does not reach a high number. Maintaining tank pressure can be performed by a guard officer who can periodically check tank pressure.

5. In the correlation of compressor compressor suction pressure (X1) and tank pressure (X2) to the length of the reliquefaction process (Y) on LPG / C Griya Borneo ship, obtained correlation coefficient data of 0.97 (ryx $1 \times 2=0.97$ ) proves that the correlation effect which is positive and very strong. Then obtained $\mathrm{r} 2=0.94$, proving that this linear regression is feasible and a coefficient of determination of $94 \%(\mathrm{KD}=94 \%)$ states that the compressor compressor suction pressure and tank pressure affect the duration of the reliquefaction process. Then in tcount $=$ $17.83(17.83>1.6923)$ and fcount $=150(150>3.34)$, where if tcount $>$ ttable and fcount $>$ ftabel then there is a significant relationship between variables $\mathrm{X} 1$ and $\mathrm{X} 2$ to $\mathrm{Y}$.

So that the rallyquefaction process does not take a long time, the LPG / C Griya Borneo ship must be able to keep the compressor compressor suction pressure stable and the tank pressure does not reach high numbers.

To maintain the compressor compressor suction pressure stable and the tank pressure does not reach high numbers. Then you must apply the maintenance management procedure properly and carry out maintenance and replacement of the compressor suction valve. Additionally the Guard Officer needs to periodically check the temperature and pressure of the tank.

\section{REFERENCE}

Arikunto, Suharsimi. 2010. Prosedur Penelitian: Suatu Pendekatan Praktik. Jakarta: PT Rineka Cipta

E. Karyanto dan Emon Paringga. 2003. Teknik Mesin Pendingin. Jakarta: CV Restu Agung.

Faires, Virgil Moring. 2004. Thermodynamics, Third Edition. New York : The Macmillan Company.

Gulo. 2002. Metodologi Penelitian. Jakarta: Gramedia Widiasarana Indonesia.

International Chamber of Shipping. 2000. Tanker Safety Guide Liquified Gas, Second Edition. London.

Lubis, Yasir Afai dan Bambang Daryanto Wonoyudo. 2014. "Teknik Pomits Vol.3" Surabaya:Jurusan Perkapalan Institute Teknologi Bandung

Mayer, Jos L. 1990. Description and Function of Cargo Handling Plant Operation Manual I. Papenburg : LPG/C Griya Borneo

Mayer, Jos L. 1990. Description and Function of Cargo Handling Plant Operation Manual I. Papenburg : LPG/C Griya Borneo

McGuire and White. 2016. Liquefied Gas Handling Principles On Ships And In Terminals Fourth Edition. London : SIGTTO.

Mahmud. 2011. Metode Penelitian Pendidikan. Bandung: Pustaka Setia.

Moh Nazir. 2011. Metode Penelitian. Bogor: Ghalia Indonesia.

Seagull. 2011. Tanker Safety Familiarization Basic Training for Liquefied Gas Tanker Operation (STCW Table A-V/1-2-1). Seagull.

Sugiyono. 2011. Metode Penelitian Kuantitatif, Kualitaif, dan R\&D. Bandung: CV Alfabeta

Susilowati, Sri Endah. 2015. "Konversi Energi dan Manufaktur Edisi Terbit I". Jakarta. Universitas Negeri Jakarta.

Woolcott. 2000. Liquified Petroleum Gas Tanker Practice. Glasgow : Brown, Son, and Ferg 